\title{
Peningkatan Produktivitas Melalui Ergonomic Pop Rice Machine di IKM XYZ Kabupaten Gowa
}

\author{
Arminas $^{1)}$, Nofias Fajri ${ }^{2)}$ \\ Jurusan Teknik Industri Agro/Politeknik ATI Makassar ${ }^{1,2}$ \\ Jl. Sunu No.220, Suangga, Kec. Tallo, Kota Makassar, Sulawesi Selatan \\ E-mail:arminas@atim.ac.id
}

\begin{abstract}
ABSTRAK
Produktivitas yang rendah merupakan masalah klasik yang dihadapi oleh berbagai Industri Kecil Menengah (IKM) di Indonesia. Rendahnya produktivitas IKM disebabkan oleh banyak faktor seperti (rendahnya kapasitas dan kualitas tenaga kerja, keterbatasan akses kepada modal, energi, teknologi, informasi dan pengetahuan) menyebabkan IKM sulit untuk menjadi besar atau bertahan pada usaha produktif dan berkelanjutan. Masalah lain yang dihadapi oleh IKM selain produktivitas adalah tidak efektifnya teknologi yang dipakai sehingga menimbulkan berbagai permasalahan pada kesehatan dan keselamatan pekerja. Pengabdian masyarakat ini dilakukan di salah satu IKM di Kabupaten Gowa. IKM XYZ bergerak dalam pembuatan bipang. Berbagai permasalahan yang ada di IKM XYZ adalah: Rendahnya kapasitas produksi, lingkungan kerja yang bising, hal ini disebabkan oleh mesin pembuat pop rice menimbulkan suara bising imtermiten. Selama proses produksi dibutuhkan energi yang besar untuk memutar mesin yang mengakibatkan pekerja merasakan keluhan pada bagian otot dan rangka pada tangan. Kegiatan yang dilakukan dalam pengabdian masyarakat ini adalah: mengidentifikasi permasalahan yang ada di IKM XYZ, melakukaan telaah permasalahan, membuat rancangan teknis, dan uji coba. Hasil dari pengabdian masyarakat ini adalah berupa mesin pop rice yang digunakan dalam memproduksi pop rice.
\end{abstract}

Kata kunci: produktivitas, pop rice, MSDS, ergonomi

\begin{abstract}
Low productivity is a classic problem faced by various Small and Medium Industries (SMEs) in Indonesia. The low productivity of SMEs is caused by many factors such as (low capacity and quality of labor, limited access to capital, energy, technology, information and knowledge) making it difficult for SMEs to grow large or survive in productive and sustainable businesses. Another problem faced by SMIs besides productivity is the ineffectiveness of the technology used, causing various problems in the health and safety of workers. This community service was carried out in one of the IKM in Gowa Regency. IKM XYZ is engaged in the manufacture of bipang. Various problems that exist in IKM XYZ are: Low production capacity, noisy work environment, this is caused by the pop rice making machine causing intermittent noise. During the production process it takes a lot of energy to rotate the machine which causes workers to feel complaints in the muscles and skeleton of the hands. The activities carried out in this community service are : identifying problems that exist in IKM XYZ, conducting problem studies, making technical designs, and testing. The result of this community service is a pop rice machine used in producing pop rice.
\end{abstract}

Keyword: productivity, pop rice, MSDS, ergonomic 


\section{Pendahuluan}

Industri Kecil Menengah (IKM) merupakan salah satu bentuk dari kegiatan ekonomi informal yang memberikan dampak sangat besar terhadap Produk Domestik Bruto (PDB) dan serapan tenaga kerja secara nasional. Pada akhir tahun 2018 tercatat bahwa lebih dari Rp 8500 trilun pada PDB atau setara 57,8 persen berasal dari IKM. Berdasarkan data Kementrian Tenaga Kerja 64 juta unit usaha IKM mampu menyerap sebesar 116 juta pekerja atau sekitar 97\% dari angkatan kerja nasional (Kemnaker, 2018). IKM ditengah kondisi pandemi COVID-19 mengalami keterpurukan yang cukup parah. Berbagai kendala dihadapi selama pandemi COVID 19, mulai dari kesulitan bahan baku, rendahnya daya beli masyarakat dan diperlakukan pembatasan kegiatan masyarakat membuat kondisi IKM menjadi semakin parah. Berbagai tantang tersebut dihadapi oleh IKM untuk keluar dari permasalahan tersebut. Bantuan pemerintah, berupa keringanan pajak, relaksasi pinjaman bank, memberikan celah bagi IKM untuk tetap eksis ditengah pandemi. Pentingnya peranan IKM pada signifikansi perekonomian nasional menjadi prioritas dalam pengembangan ekonomi. Strategisnya peranan IKM serta diikuti oleh kompetisi yang ketat dengan berbagai perusahaan besar membuat sektor IKM menjadi kurang strategis. Persaingan yang menjadi semakin ketat, IKM harus kreatif dalam bersaing pada era global (Sasono, dkk, 2014).

Berbagai permasalahan dihadapi oleh IKM menyebabkan proyeksi bisnis IKM menjadi jalan ditempat. Salah satu permasalahan utama yang dihadapi oleh IKM adalah rendahnya produktivitas. Rendahnya produktivitas IKM disebabkan oleh berbagai permasalahan yang ada di IKM. Hal ini disebabkan oleh produktivitas per unit usaha maupun tenaga kerja. Berbagai kendala yang dihadapi IKM seperti rendahnya kapasitas dan kualitas sumber daya manusia, keterbatasan akses kepada sumber daya yang produktif seperti (modal, bahan baku, teknologi, informasi dan pengetahuan). Kendala-kendala tersebut menyebabkan IKM masih selalu berada pada level usaha mikro atau kecil dan sulit untuk mencapai usaha besar atau bertahan dengan usaha yang produktif dan berkelanjutan. Produktivitas yang rendah di IKM merupakan tingkat produksi yang dapat dikerjakan selama per tahun. Hal ini diakibatkan oleh kinerja IKM yang masih berbasis tradisi dengan sistem yang serba manual. Menghadapi pasar yang dinamis dan semakin ketat membuat IKM wajib melakukan perubahan dari berbagai hal. Pengembangan produk, pasar dan teknologi sangat dibutuhkan untuk menciptakan daya saing yang tinggi. Potensi dalam pengembangan IKM akan dapat menyerap tenaga kerja sehingga menekan angka pengangguran dan kemiskinan. IKM memiliki potensi yang besar untuk dikembangkan dalam memanfaatkan semua sumber daya yang dimiliki baik sumber daya alam, sumber daya manusia dan budaya lokal, sehingga akan menjadi kekuatan ekonomi masyarakat setempat. (Kurniawati, dkk, 2021).

Produktivitas bukan menjadi kendala satu-satunya yang membuat kondisi IKM jalan ditempat. Tidak efisiennya teknologi yang dipakai, kondisi lingkungan kerja yang buruk membuat IKM semakin tidak efektif dalam menjalankan kegiatan bisnisnya. Teknologi yang tidak baik dapat membuat kapasitas produksi yang rendah, kualitas produk yang kurang baik, sehingga ketika produk tersebut tidak dapat bersaing secara global. Kualitas lingkungan kerja yang buruk akan mengakibatkan penurunan produktivitas pekerja dan juga menimbulkan ketidaknyamanan selama bekerja yang berdampak negatif baik pada saat bekerja atau dapat menimbulkan penyakit akibat kerja pada masa yang akan datang. Fasilitas kerja yang baik akan memberikan produktivitas dan wellbeing yang baik kepada para pekerja. Salah satu permasalahan lingkungan kerja adalah masalah lingkungan kerja fisik (bising, panas, dan pencahayaan). Kebisingan merupakan bunyi yang tidak diinginkan atau mengganggu dari suatu usaha atau kegiatan dalam tingkat waktu tertentu yang mampu menimbulkan masalah kesehatan (Suma'mur, 2009). Frekuensi kebisingan juga menjadi suatu hal penting dalam menentukan perasaan yang subjektif, namun bahaya di area kebisingan tergantung pada frekuensi bising yang ada (Ridley, 2003). Salah satu efek kebisingan paling berbahaya adalah ketulian pada pra pekerja yang terus terpapar oleh kebisingan tersebut. Selain kebisingan kelelahan kerja yang disebabkan oleh kerja manual sangat berpengaruh terhadap kesehatan dan keselamatan pekerja serta

produktivitas pekerja. Jika peralatan yang digunakan tidak ergonomis akan menyebabkan 
muscholuskeletal disorders (MSDS) atau kelainan otot rangka yang akan mengganggu kinerja pekerja.

\section{Tinjauan Pustaka}

Ergonomi merupakan cabang ilmu yang sistematis dalam memanfaatkan informasi-informasi mengenai sifat, kemampuan dan keterbatasan manusia dalam melaksanakan pekerjaannya sehingga dapat bekerja dan hidup dengan produktiv dan wellbeing melalui pekerjaan yang efektif, aman dan nyaman (Sutanlaksana, 1979). Dalam perkembangan ilmu ergonomi ruang lingkup tersebut berkembang menjadi: ergonomi fisik yang berhubungan dengan anatomi tubuh, antrhopometri dan lain-lain, ergonomi kognitif yang berhubungan dengan proses mental manusia (presepsi, ingatan, reaksi), ergonomi organisasi yang berkaitan dengan optimasi sistem sosioteknik, termasuk kebijakan dalam sruktur organisasi maupun kebijakan proses, dan ergonomi lingkungan yang berkaitan dengan lingkungan fisik kerja seperti kebisingan, temperatur, getaran dan pencahayaan.

Lingkungan kerja menjadi faktor dalam memberikan kenyamanan dan produktivitas kepada para pekerja. Lingkungan kerja meliputi semua bahan, peralatan, kondisi sekitar tempat kerja dimana seorang individu bekerja (Sedarmayanti, 2001). Salah satu yang menjadi acuan dalam ergonomi lingkungan adalah masalah polusi bunyi atau biasa disebut kebisingan. Bunyi yang tidak dikehendaki dalam jangka waktu yang lama akan mengganggu kinerja dan kondisi kesehatan pekerja. Merusak sistem pendengaran yang akhirnya dapat mengganggu komunikasi. Ada beberapa aspek yang akan menentukan kualitas bunyi dan menentukan tingkat gangguan terhadap manusia yang mendengarnya.

1. Lama waktu bunyi tersebut terdengar oleh manusia, semakin lama telinga seseorang mendengar kebisingan maka akan semakin buruk efeknya bagi pendengaran (efek tuli)

2. Intensitas, biasanya intensitas bunyi diukur dan dinyatakan dalam desibel (db).

3. Frekuensi, dimana menunjukkan jumlah gelombang suara yang sampai ditelinga seseorang dalam setiap detik, dinyatakan dalam Hz.

Intensitas suara semakin tinggi sampai ditelinga seseorang maka kebisingan tersebut akan semakin keras. Kebisingan dengan frekuensi yang tinggi akan lebih berbahaya dari pada frekuensi lebih rendah. Waktu paparan juga akan mempengaruhi akibat kebisingan, semakin lama terpapar maka akibatnya akan semakin besar. Selain hal diatas faktor lain yang diperhatikan dalam studi kebisingan adalah kebisingan tersebut bersifat tetap (stedy) atau berupa terputus-putus (intermittent). Penyakit akibat kebisingan berakibat pada pendengaran manusia terjadi karena kumulatif dari suara diatas intensitas maksimal dalam waktu yang lama dari pada waktu yang diizinkan untuk intensitas kebisingan tersebut.

Pengaruh kebisingan dapat dikategorikan menjadi dua bagian yaitu:

1. Pengaruh kebisingan dengan intensitas yang tinggi

a. Pengaruh pemaparan kebisingan dalam intensitas tinggi menyebabkan terjadinya kerusakan pada indera pendengaran yang menyebabkan penurunan nilai daya pendengaran secara permanen yang terlebih dahulu dimulai dengan penurunan fungsi pendengaran sementara.

b. Pengaruh kebisingan akan sangat memberikan efek jika jenis kebisingan intermedient (terputus-putus) yang sumber kebisingannya tidak diketahui.

c. Secara fisiologis, kebisingan dalam intensitas yang tinggi menyebabkan gangguan kesehatan seperti: peningkatan tekanan darah, risiko serangan jantung meningkat, dan mengalami gangguan pencernaan.

2. Pengaruh kebisingan pada intensitas yang rendah

a. Kebisingan dengan intensitas yang rendah secara fisiologis tidak menimbulkan kerusakan secara fisiologis tetapi akan menyebabkan penurunan performansi kerja, sebagai salah bentuk munculnya stres kerja akibat gangguan dari luar. 
NASA pada tahun 1989 melakukan penelitian tentang efek yang terjadi akibat kebisingan dimana didapatkan bahwa:

1. Bila intensitas kebisingan meningkat, maka peningkatan tersebut dapat mempengaruhi perbaikan dan kinerja. Ketika melebihi intensitas tertentu maka akan terjadi penurunan kinerja.

2. Kebisingan yang datang secara mendadak diharapkan menyebabkan respon yang mengejutkan sehingga mengganggu kinerja dan konsentrasi.

3. Kebisingan yang terjadi secara periodik dapat mengurangi konsentrasi jika bekerja dalam pekerjaan yang rumit.

4. Efek psikologis lain yang muncul adalah kegelisahan, perasaan tidak berdaya yang akan mengganggu performansi kerja.

Musculouskeletal Disorder (MSDS) merupakan salah satu bentuk kelainan yang disebabkan oleh penumpukan kerusakan-kerusakan kecil otot dan rangka yang disebabkan oleh cidera berulang yang kadang tidak bisa sembuh total, sehingga dapat menciptakan kerusakan yang permanen (Tarwaka, 2014). Beberapa keluhan dalam MSDS seperi keluhan sakit, nyeri, pegal-pegal dan lainnya yang terjadi pada sistem otot (musculouskeletal) seperti pembuluh darah, tendon, sendi, tulang, syaraf dan lain-lain yang diakibatkan oleh sistem kerja yang tidak baik. Beberapa hal yang dapat menyebabkan keluhan musculouskeletal adalah peregangan otot yang berlebihan, aktivitas yang dilakukan secara berulang-ulang, serta postur tubuh yang tidak alamiah. Beberapa faktor individu yang menyebabkan terjadinya MSDS adalah faktor usia, jenis kelamin, kebiasaan dalam merokok, dan masa kerja.

Secara garis besar masalah keluhan otot dapat dikelompokkan menjadi dau bagian:

1. Keluhan bersifat sementara (reversible), yaitu keluhan yang dapat terjadi saat otot menerima beban statis, namun demikian keluhan tersebut akan hilang apabila pembebanan hilang.

2. Keluhan yang bersifat menetap (perisistent), yaitu keluhan yang bersifat menetap, walaupun pembebanan dihentikan, namun sakit pada otot masih terus terasa.

\section{Metodologi Penelitian}

Kegiatan pengabdian masyarakat ini dilakukan di IKM XYZ yang berlokasi di Kabupaten Gowa, Provinsi Sulawesi Selatan. IKM ini bergerak dalam pembuatan makanan khas daerah seperti bipang. Bipang merupakan suatu jenis makanan yang terbuat dari beras. Sebelum menjadi bipang beras diubah menjadi pop rice. Proses produksi di IKM XYZ masih bersifat manual dengan alat bantu yang belum menggunakaan kaidah ergonomis. Berbagai keluhan dan masalah yang ditemukan dalam produksi pop rice tersebut adalah: mesin masih semi manual yang memerlukan tenaga ekstra untuk memutar mesin secara terus menerus, mesin menghasilkan suara yang cukup keras pada saat produk akan matang, sehingga akan menimbulkan kebisingan intermiten (terputus) yang bisa memimbulkan permasalahan pendengaran pada para pekerja. Karena proses produksi masih manual sehingga produktivitas produksi harian menjadi rendah, hal ini disebabkan oleh kapasitas produksi yang rendah.

Secara lebih detail, kegiatan pengabdian masyarakat ini berlangsung dari bulan Juli- September 2021, dengan tahapan kegiatan sebagai berikut ini:

1. Kunjungan awal untuk mengidentifikasi permasalahan-permasalahan yang ada di IKM XYZ.

2. Proses telaah permasalahan yang ada dilakukan untuk penapisan permasalahan yang ada di IKM XYZ sehingga terpilih permasalahan yang paling kritis untuk diselesaikan segara.

3. Pembuatan rancangan melalui gambar teknis terhadap mesin pembuatan pop rice

4. Penyerahan dan uji coba mesin pop rice ke IKM untuk digunakan dalam proses produksi 
Adapun alur kegiatan pengabdian masyarakat ini dapat dilihat pada Gambar 1

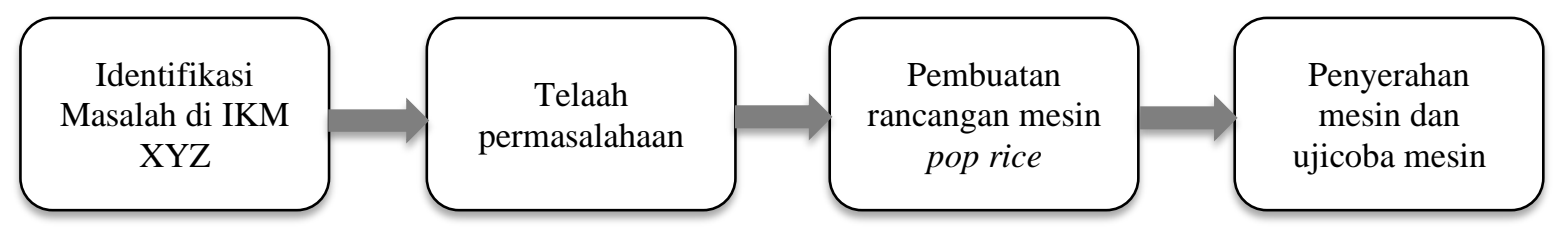

Gambar 1. Blok Diagram Kegiatan Pengabdian Masyarakat IKM XYZ Gowa

\section{Hasil dan Pembahasan}

Pelaksanaan dari setiap rencana aktivitas dalam pengabdian masyarakat di IKM XYZ Kabupaten Gowa adalah sebagai berikut:

1. Identifikasi permasalahan yang ada di IKM XYZ Kabupaten Gowa.

Identifikasi permasalahan yang ada di IKM dilakukan dengan proses deep interview dengan pemilik dan pekerja pada bagian produksi di IKM XYZ. Berbagai permasalahan ditemukan adalah:

a. Rendahnya kapasitas produksi yang disebabkan oleh kapasitas produksi yang masih rendah.

b. Lingkungan kerja yang bising, hal ini disebabkan oleh mesin pembuat pop rice yang ada menimbulkan suara bising imtermiten yang keras saat produk akan matang.

c. Selama proses produksi dibutuhkan energi yang besar untuk memutar mesin yang mengakibatkan pekerja merasakan keluhan pada bagian otot dan rangka pada tangan.

d. Banyaknya pop rice yang terbuang selama proses produksi, karena wadah penampung yang tidak efektif digunakan.

Gambar mesin yang digunakan dalam produksi pop rice saat ini dapat dilihat pada Gambar 2.

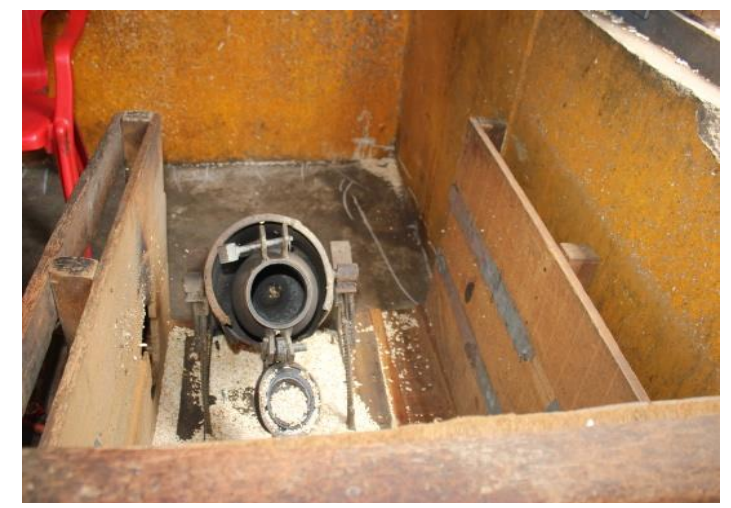

Gambar 2. Kondisi Mesin Pop Rice IKM XYZ Sebelum di Perbaharui

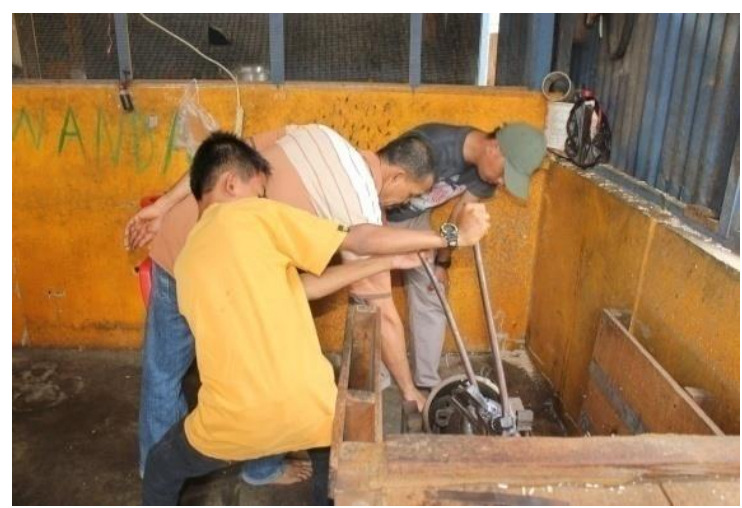

Gambar 3. Kondisi Mesin Pop Rice Saat Produksi Berlangsung 


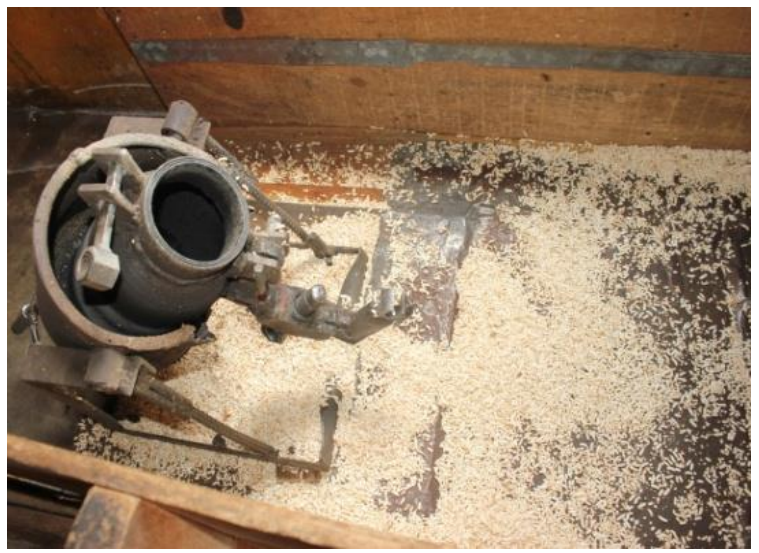

Gambar 4. Loss Product dari Mesin Sebelum diperbaiki

2. Proses telaah permasalahan yang ada dilakukan untuk penapisan permasalahan yang ada di IKM XYZ sehingga terpilih permasalahan yang paling kritis untuk diselesaikan segara.

Setelah semua permasalahan di identifikasi, dilakukan proses telaah permasalahan-permasalahan tersebut. Maka didapatkan suatu ide untuk membuat mesin pop rice yang ergonomis. Karena dengan inovasi mesin pop rice tersebut akan menyelesaikan beberapa permasalahan seperti:

a. Peningkatan produktivitas yang disebabkan kapasitas produksi yang meningkat.

b. Menyelesaikan masalah kebisingan yang ditimbulkan oleh mesin yang lama.

c. Mesin dibuat sesuai postur kerja pekerja yang alamiah, sehingga lebih ergonomis dan mengurangi keluhan masalah otot dan rangka pada pekerja

d. Mengurangi loss product yang diakibatkan wadah penampungan yang tidak efektif.

3. Pembuatan rancangan melalui gambar teknis terhadap mesin pembuatan pop rice

Setelah didapatkan inovasi, semua ide diwujudkan dalam bentuk gambar teknis desain mesin pop rice yang akan diusulkan. Adapun gambar teknis desain mesin pop rice usulan dapat dilihat pada Gambar 5.

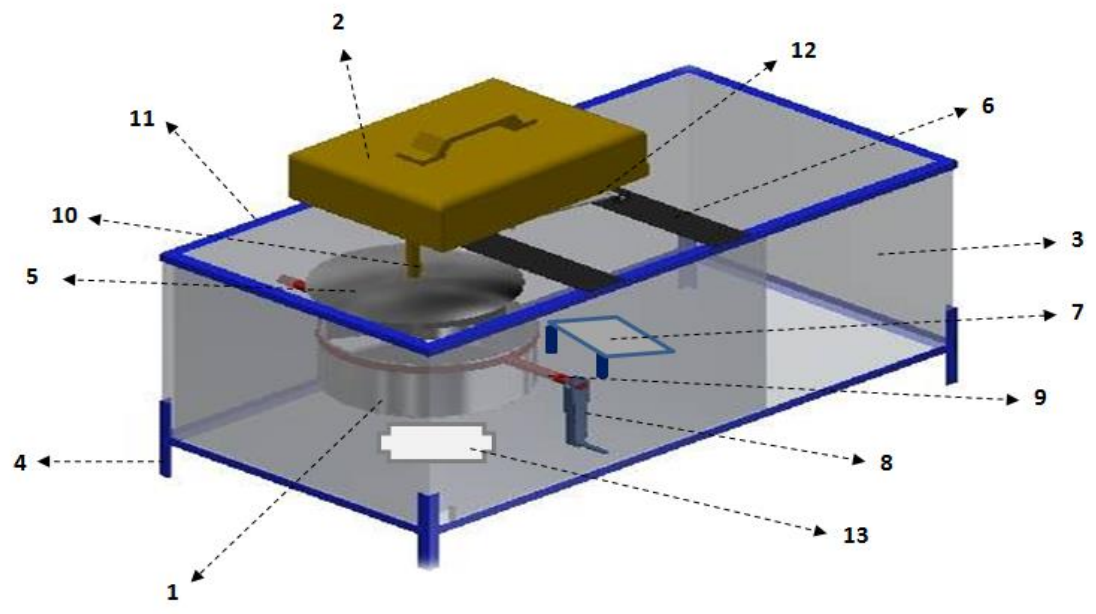

Gambar 5. Gambar Teknis Mesin Pop Rice Usulan

Keterangan

1. Panjang $=100 \mathrm{~cm}$

2. Lebar $=50 \mathrm{~cm}$

3. Tinggi $=50 \mathrm{~cm}$

4. Tinggi Kaki Mesin $=30 \mathrm{~cm}$

5. Kapasitas Pop rice $=2$ liter 
4. Penyerahan dan uji coba mesin pop rice ke IKM untuk digunakan dalam proses produksi Hasil dari gambar teknis mesin pop rice diwujudkan menjadi mesin pop rice usulan yang selanjutnya diserahkan dan dilakukan uji coba penggunaan mesin tersebut. Kegiatan uji coba mesin pop rice dapat dilihat pada Gambar 6. Mesin pembuatan pop rice yang direkomendasikan mengurangi terjadinya loss product yang terjadi selama proses pembuatan pop rice.

Adapun cara menggunakan mesin pop rice adalah sebagai berikut:

a. Bersihkan terlebih dahulu mesin sebelum digunakan

b. Masukan bahan baku pembuatan pop rice

c. Tutup panci dengan penutup dengan erat

d. Hubungkan mesin dengan listrik

e. Mesin akan mengaduk dengan otomatis

f. Perhatikan letupan dari pop rice, jika sudah tidak terdengar letupan maka proses selesai

g. Angkat mixer kemudian tuangkan pop rice dengan cara diputar

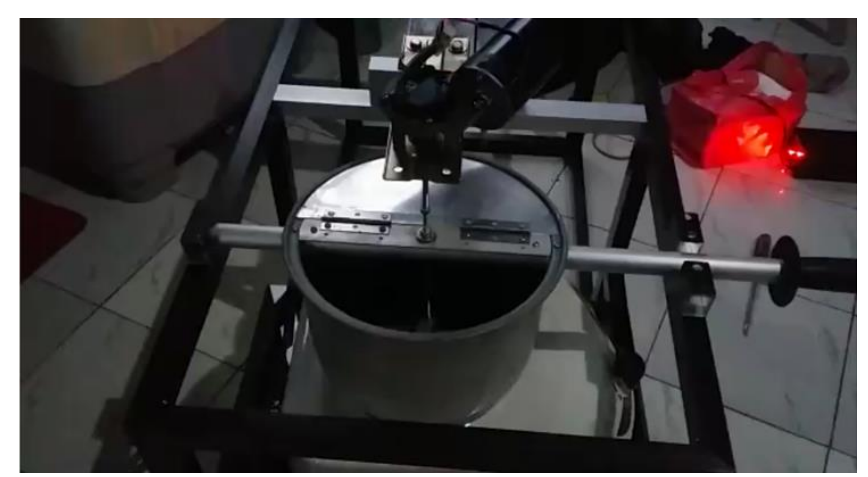

\section{Kesimpulan}

Gambar 6. Uji Coba Mesin Pop Rice

Produktivitas produksi akan tercapai jika semua elemen-elemen yang mempengaruhi proses produksi bekerja dengan baik dan sesuai dengan sifat alamiahnya. Kesimpulan dan saran dari rangkaian kegiatan pengabdian masyarakat ini adalah sebagai berikut:

1. Kegiatan produksi yang berlangsung di IKM Nabila saat ini masih kurang produktif karena berbagai permasalahan seperti: kapasitas mesin, mesin yang tidak ergonomis

2. Inovasi dilakukan dengan membuat mesi pembuat pop rice usulan yang ergonomis.

3. Mesin pop rice menggunakan mixer tunggal dengan pengaduk otomatis menggunakan dinamo dan energi listrik yang memudahkan para pekerja.

\section{Daftar Pustaka}

Kemnaker, (2021, 11 Oktober). UMKM Berkontribusi Besar Terhadap Serapan Tenaga Kerja. 10 Juli 2020. https://jabarprov.go.id/index.php/news/39551/2020/10/07/UMKM-BerkontribusiBesar-Pada-Serapan-Tenaga-Kerja.

Kurniati, dkk. (2021). Determinasi Sumber Daya Manusia, Modal Usaha dan Pemasaran Terhadap Perkembangan UMKM Tas. Equilibrium Jurnal Ilmiah Ekonomi dan Pembelajarannya. Vol 9, No 1 (2021).

Ridley, (2003). Noise and Nuisances. New York: Springer.

Sasono, dkk. (2014). Manajemen Inovasi Pada Usaha Kecil dan Menengah. Jurnal STIE Semarang, Volume 6 Edisi Oktober 2014.

Serdamayanti. (2001). Sumber Daya Manusia dan Produktivitas Kerja. Jakarta: Mandar Jaya.

Suma'mur P. K. (2009). Higene Perusahaan dan Kesehatan Kerja. Jakarta: PT. Toko Gunung Agung. Sutalaksana, Iftikar Z. (1979). Teknik Perancangan Sistem Kerja. Bandung: ITB.

Tarwaka. (2014). Ergonomi Industri (Dasar-dasar pengetahuan ergonomi dan aplikasi ditempat kerja). Surakarta: Harapan Press. 
Wignjosoebroto. (1995). Ergonomi Studi Gerak dan Waktu. Jakarta: Penerbit Guna Widya.

.(2013). Perancangan Lingkungan Kerja dan Alat Bantu yang Ergonomis untuk Mengurangi Masalah Back Injury dan Tingkat Kecelakaan Kerja pada Departemen Mesin Bubut (Studi Kasus PT Atak Indometal Ngingas Waru-Sidoarjo). Skripsi Institut Teknologi Sepuluh Nopember.

Winursito, (2016). Penerapan Ergonomi Makro Terhadap Kinerja Pekerja Guna Meningkatkan Keuntungan Perusahaan (Studi Kasus di PT Karya Putra Manunggal Temanggung), Skripsi Universitas Pembangunan Nasional "Veteran". Yogyakarta 